\title{
Evidence for Increased Oxidative Damage in Patients with Cystic Fibrosis
}

\author{
R. K. BROWN AND F. J. KELLY \\ Cardiovascular Research, The Rayne Institute, St Thomas' Hospital, \\ London, SEI 7EH, England
}

\begin{abstract}
Patients with cystic fibrosis (CF) may be more susceptible to oxidative cell injury than normal healthy children due to both the impaired absorption of antioxidant nutrients and the increased oxidative stress caused by chronic pulmonary infections. The purpose of this study was to examine whether markers of oxidative damage to lipids (malondialdehyde-like substances and lipid hydroperoxides) and proteins (protein carbonyls) were present in the plasma of CF patients. Mean values $( \pm$ SD) of thiobarbituric acid-reactive substances were significantly higher in patients $(6.93 \pm 1.47 \mu \mathrm{mol} / \mathrm{L} ; n=25)$ than in controls $(5.84$ $\pm 0.59 \mu \mathrm{mol} / \mathrm{L} ; n=10$ ). FFA hydroperoxides were not detected in control subjects (the detection limit of the assay was $0.02 \mu \mathrm{mol} / \mathrm{L}$ ), but in 11 of the $33 \mathrm{CF}$ patients studied they were found in a range of $0.03-0.34 \mu \mathrm{mol} / \mathrm{L}$. Plasma protein carbonyl concentrations did not differ significantly between the two groups $(p=0.076)$, although a much wider distribution was observed in the CF patients (range $0.17-5.64 \mathrm{nmol} / \mathrm{mg}$ protein) than in the control group (range $0.24-1.55 \mathrm{nmol} / \mathrm{mg}$ protein). No correlation was found between thiobarbituric acid-reactive substances and FFA
\end{abstract}

The concept that free radicals play a significant role in the pathogenesis of certain diseases such as postischemic reperfusion-induced injury (1), atherosclerosis (2), cancer $(3)$, and $\mathrm{CF}(4,5)$ is becoming increasingly recognized. Consequently, interest has been growing in the mechanisms of antioxidant protection and in the development of methods to quantify the resulting free radicalinduced damage. Recently, we reported that children with CF had reduced peroxyl-radical trapping potential and that this was due, in part, to abnormal nutrient handling (6). An adequate and balanced diet is essential for achieving and maintaining the normal complement of antioxidant defenses (7). It is therefore not surprising that

Received October 25, 1993; accepted May 3, 1994.

Correspondence and reprint requests: Dr. F. J. Kelly, Cardiovascular Research, The Rayne Institute, St Thomas' Hospital, Lambeth Palace Road, London SE1 7EH UK.

Supported by funds from the Cystic Fibrosis Trust. hydroperoxides or between either of these markers and protein carbonyl content. Concentrations of plasma vitamin $E$, vitamin $C$, and protein sulfhydryls were within the normal ranges in both control subjects and CF patients. The concentration of uric acid was significantly reduced ( $p$ $<0.01)$ in the CF group $(204 \pm 96.99 \mu \mathrm{mol} / \mathrm{L})$ compared with that in control subjects $(352 \pm 81.11 \mu \mathrm{mol} / \mathrm{L})$, but reduction in plasma levels of this antioxidant did not correlate with increased markers of free radical damage. These results indicate that certain CF patients are more susceptible to oxidative damage, even in the presence of relatively normal concentrations of the major plasma antioxidants; these patients may benefit from increased antioxidant consumption. (Pediatr Res 36: 487-493, 1994)
CF, cystic fibrosis

\section{Abbreviations}
DNP, 2,4-dinitrophenylhydrazine
RTLF, respiratory tract lining fluid
TBA, thiobarbituric acid

these defenses are frequently disordered in CF patients with malabsorption problems.

A variety of studies have shown that the immune response in patients with $\mathrm{CF}$ is increased $(8,9)$, and analysis of bronchoalveolar lavage fluid has revealed a 1000 -fold increase in the number of neutrophils recovered from the lungs compared with controls (10). Because it is well established that neutrophils, when activated, are a major source of free radicals (11), it follows that those CF patients with marginal or depleted antioxidant defenses are likely to exhibit evidence of increased oxidative stress, especially during episodes of acute pulmonary infection. Results from our previous study (6) support such a hypothesis; we found that CF plasma had a reduced capacity to withstand increased oxidative damage in vitro, indicating that patients may be more sensitive to free radical-mediated attack in vivo.

The purpose of the present study was to examine the hypothesis that patients with $\mathrm{CF}$ are more susceptible to 
free radical-induced oxidative injury than healthy agematched controls. We investigated two sensitive markers of lipid peroxidation (TBA-reactive substances and FFA hydroperoxides) and one marker of protein oxidation (protein carbonyls), using stringent precautions to prevent the loss of these labile markers or their spurious production during the preparation and analysis of the samples.

\section{METHODS}

Chemicals. All chemicals used were obtained from Sigma (Poole, England) and HPLC-grade solvents were obtained from Rathburn Chemicals (Winterburn, Scotland). 15(S)hydroperoxyeicosatetraenoic acid standard was obtained from Cascade Bioactive Lipids (Reading, England).

Subjects. Venous blood samples were collected from both control subjects and patients with CF. Patients were attending the CF clinic at Southampton General Hospital, for a regular (6 monthly) checkup and did not present with specific problems. The mean age of the CF group was $10 \mathrm{y}, 3 \mathrm{mo}(n=45$, range $=2 \mathrm{y}, 11 \mathrm{mo}$ to $18 \mathrm{y})$. The control group comprised patients attending St Thomas' Hospital Ear, Nose, and Throat Department for blood tests before tonsillectomy; they had a mean age of $7 \mathrm{y}, 11$ mo $(n=11$, range $=2 \mathrm{y}, 4$ mo to $21 \mathrm{y}, 4 \mathrm{mo})$. Ethical permission for this study was obtained from the Joint Ethical Subcommittee, Southampton and South West Hampshire Health Authority, for the CF patients and from the West Lambeth Health Authority Ethics Committee for the control subjects.

Sample handling. Blood (4 mL) was collected from CF patients and controls and immediately divided equally between two heparinized tubes on ice, one of which contained $20 \mu \mathrm{L}$ of $2 \mathrm{mmol} / \mathrm{L}$ butylated hydroxytoluene and $20 \mu \mathrm{L}$ of $2 \mathrm{mmol} / \mathrm{L}$ Desferal (Sigma Chemical Co., Poole, Dorset, UK). The blood was then centrifuged at $1500 \mathrm{rpm}$ at $4^{\circ} \mathrm{C}$ for $10 \mathrm{~min}$ and the plasma stored at $-80^{\circ} \mathrm{C}$ for up to $4 \mathrm{wk}$ before being analyzed. Plasma samples protected with butylated hydroxytoluene and Desferal were used to determine the concentration of oxidative markers, whereas those without additional antioxidants were used to determine individual antioxidant concentrations. All variables measured were found to be stable under the conditions of storage.

Determination of $\alpha$-tocopherol. Aliquots of $100 \mu \mathrm{L}$ of plasma were extracted with $100 \mu \mathrm{L}$ of anhydrous HPLCgrade ethanol and $400 \mu \mathrm{L}$ of HPLC-grade hexane. $\alpha$-Tocopherol acetate was added as an internal standard. The hexane layer was removed and evaporated to dryness under a stream of nitrogen. The extract was then redissolved in $400 \mu \mathrm{L}$ of HPLC-grade methanol, and $100-\mu \mathrm{L}$ aliquots were analyzed by HPLC. A $7 \times 100-\mathrm{mm}, 5-\mu \mathrm{m}$ C18 column (Jones Chromatography, Hengoed, Wales, UK) was eluted with methanol:water $(39: 1 \mathrm{vol} / \mathrm{vol})$, at a flow rate of $0.8 \mathrm{~mL} / \mathrm{min}$. Detection was by absorbance at $292 \mathrm{~nm}(12)$.
Determination of ascorbic acid and uric acid. The HPLC determination of uric acid and ascorbate was based on the method of Iriyama et al (13). Plasma $(100 \mu \mathrm{L})$ was extracted with $400 \mu \mathrm{L}$ of $2 \%$ metaphosphoric acid and $100 \mu \mathrm{L}$ of HPLC-grade heptane. Samples were vortex mixed for $40 \mathrm{~s}$ and then centrifuged at $13000 \times g$ for 5 min. Aliquots of $20 \mu \mathrm{L}$ were injected for analysis using a Gilson model 231 autosampler (Gilson Medical Electronics, France). A $10 \times 300-\mathrm{mm}, 5-\mu \mathrm{m} \mathrm{C} 18$ column was eluted with a $0.2 \mathrm{~mol} / \mathrm{L} \mathrm{K} \mathrm{KPO}_{4}-\mathrm{H}_{3} \mathrm{PO}_{4}$ running buffer, $\mathrm{pH} 2.1$, containing $0.25 \mathrm{mmol} / \mathrm{L}$ octanesulfonic acid at a flow rate of $1.8 \mathrm{~mL} / \mathrm{min}$. An EG \& G electrochemical detector (Jones Chromatography) was used for detection, with $\mathrm{E}$ (applied potential between the working and reference electrode) set at $810 \mathrm{mV}$, time constant set at $5 \mathrm{~s}$, cathodic output, and a sensitivity of $100 \mathrm{nA}$.

Determination of total plasma sulfhydryls. Plasma sulfhydryls were assayed by the method of Ellman (14), in which $25 \mu \mathrm{L}$ of plasma were added to $975 \mu \mathrm{L}$ of $0.2 \mathrm{~mol} / \mathrm{L}$

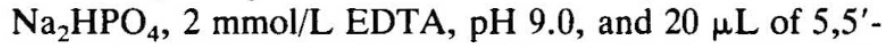
dithio-bis(2-nitrobenzoic) acid $(10 \mathrm{mmol} / \mathrm{L}$ in $0.05 \mathrm{~mol} / \mathrm{L}$ phosphate buffer, $\mathrm{pH} 7.0$ ). Absorbance at $412 \mathrm{~nm}$ was determined on an LKB Ultraspec II spectrophotometer (LKB Biochrom Ltd., Cambridge, UK) against an appropriate blank and the concentration of sulfhydryls calculated using the equation $c=A / \epsilon \times d$, where $A=$ absorbance, $\epsilon=$ the extinction coefficient (13 600), and $d=$ the path length $(1 \mathrm{~cm})$.

TBA determination of lipid hydroperoxides. The method used was an adaptation of the original assay described by Yagi (15). A tube containing $2.0 \mathrm{~mL}$ of $12 \mathrm{~N} \mathrm{H}_{2} \mathrm{SO}_{4}$ and $10 \mu \mathrm{L}$ of plasma had added to it $0.25 \mathrm{~mL}$ of $10 \% \mathrm{wt} / \mathrm{vol}$ phosphotungstic acid; it was then left to stand at room temperature for $5 \mathrm{~min}$ before being spun at $13000 \times g$ for $10 \mathrm{~min}$ at room temperature. The supernatant was discarded and the pellet resuspended in $1.0 \mathrm{~mL}$ of $12 \mathrm{~N}$ $\mathrm{H}_{2} \mathrm{SO}_{4}$ and $0.15 \mathrm{~mL}$ of $10 \%$ vol/vol phosphotungstic acid. The mixture was again centrifuged at $13000 \times g$ for 10 min at $10^{\circ} \mathrm{C}$. The pellet was resuspended in $2.0 \mathrm{~mL}$ of water by vigorous mixing, and $0.5 \mathrm{~mL}$ of TBA reagent (a mixture of equal volumes of $0.67 \%$ TBA aqueous solution and glacial acetic acid) was added and the reaction mixture heated at $95^{\circ} \mathrm{C}$ for $60 \mathrm{~min}$ in a water bath. After cooling on ice, $2.5 \mathrm{~mL}$ of butan-1-ol were added and the mixture was vortexed for $20 \mathrm{~s}$. The final solution was centrifuged again at $13000 \times g$ for $10 \mathrm{~min}$ and the n-butanol layer removed for fluorometric detection at 553 $\mathrm{nm}$ with excitation at $515 \mathrm{~nm}$ against an appropriate blank. The lipid peroxide concentration was determined by producing a standard curve (range $=0.04-0.125$ $\mu \mathrm{mol} / \mathrm{L}$ ) obtained by reacting different concentrations of tetraethoxypropane with TBA and then treating them in the same way as the plasma samples. All samples were run in duplicate with an intraassay variability of $<10 \%$.

HPLC determination of plasma lipid hydroperoxides. Lipid hydroperoxide extraction from plasma was carried out on ice in glass tubes protected from light. To $0.5 \mathrm{~mL}$ of plasma, $0.25 \mathrm{~mL}$ of $0.2 \mathrm{~mol} / \mathrm{L}$ citric acid was added 
followed by $6 \mathrm{~mL}$ of hexane. The samples were mixed vigorously and centrifuged at $2000 \mathrm{rpm}$ for $5 \mathrm{~min}$ at $4^{\circ} \mathrm{C}$. The upper layer was removed and dried under a stream of nitrogen while shielded from light. The extract was redissolved in $100 \mu \mathrm{L}$ of methanol, and $20-\mu \mathrm{L}$ samples were injected onto a C18 column and eluted with methanol containing $0.02 \%$ triethylamine at a flow rate of 1 $\mathrm{mL} / \mathrm{min}$. The reaction solution, consisting of $1 \mathrm{mmol} / \mathrm{L}$ isoluminol in methanol $0.1 \mathrm{~mol} / \mathrm{L}$ and sodium borate buffer, $\mathrm{pH} 10$ (30:70, vol/vol), was made up $24 \mathrm{~h}$ before use to ensure that the intrinsic chemiluminescence had diminished and so would not affect the results. It was then added to microperoxidase dissolved in $10 \mathrm{mmol} / \mathrm{L}$ Tris, $\mathrm{pH} 7.4$, to a final concentration of $1 \mu \mathrm{g} / \mathrm{mL}$ and filtered through a $0.45-\mu \mathrm{m}$ membrane before use. After passing through the UV detector, the running buffer was mixed with the reaction mixture via a T-joint and incubated in a 15-s mixing coil. The chemiluminescence generated by the presence of hydroperoxides was detected using an Applied Biosystems 980 fluorometric detector (Applied Biosystems, Ramsey, NJ) acting as a photomultiplier at $550 \mathrm{~nm}$ with a range setting of 0.001 A. A standard curve of $15(\mathrm{~S})$ hydroperoxyeicosatetraenoic acid (range $=1.83-14.71 \mathrm{pmol} / \mathrm{L}$ ), which is equivalent to a plasma concentration of $0.02-0.15 \mu \mathrm{mol} / \mathrm{L}$ with the detection limit of the assay being $0.02 \mu \mathrm{mol} / \mathrm{L}$, was run. All the standards and the samples were run in duplicate, with an intraassay variability of $<10 \%$.

Determination of carbonyl content. The assay used was based on that developed by Levine et al (16). An aliquot of $100 \mu \mathrm{L}$ of plasma was diluted 2 -fold in $5 \mathrm{mmol} / \mathrm{L}$ EDTA, $\mathrm{pH}$ 7.4. This sample was then divided into two separate aliquots, precipitated with $500 \mu \mathrm{L}$ of $20 \%$ trichloroacetic acid, and centrifuged at $13000 \times g$ for 3 min. Both supernatants were discarded; one pellet was redissolved in $2 \mathrm{~mol} / \mathrm{L} \mathrm{HCl}$ containing $0.1 \%$ DNP solution and the other, which acted as the blank and was run in parallel, in $2 \mathrm{~mol} / \mathrm{L} \mathrm{HCl}$ alone. The pellets were sonicated at 14 microns (vibration units) for $10 \mathrm{~s}$ to aid dissolution. The samples were then left to stand at room temperature for $1 \mathrm{~h}$ with vigorous mixing every $15 \mathrm{~min}$; at the end of this period, $500 \mu \mathrm{L}$ of $20 \%$ trichloroacetic acid were added to reprecipitate the protein; the mixture was then centrifuged at $13000 \times g$ for $3 \mathrm{~min}$. The pellets were washed three times with $1 \mathrm{~mL}$ of ethanol/ethyl acetate (1:1) to remove the free reagent, with the sample allowed to stand for $10 \mathrm{~min}$ before centrifugation and the supernatant discarded each time. The final pellet produced from these washings was redissolved in $1 \mathrm{~mL}$ of $6 \mathrm{~mol} / \mathrm{L}$ guanidine- $\mathrm{HCl}$ by warming gently at $37^{\circ} \mathrm{C}$ for $15 \mathrm{~min}$ followed by sonication at 14 microns for $10 \mathrm{~s}$. After a last spin at $13000 \times g$ for $3 \mathrm{~min}$, the absorbance of each sample and its corresponding blank was read against a blank containing $6 \mathrm{~mol} / \mathrm{L}$ guanidine- $\mathrm{HCl}$ using an LKB Ultraspec II at a wavelength of $370 \mathrm{~nm}$. The carbonyl content was calculated using the equation $c=A / \epsilon \times d$, where $A=$ absorbance, $\epsilon=$ extinction coefficient $(22000$ $\left.\mathrm{mol} / \mathrm{L}^{-1} \mathrm{~cm}^{-1}\right)$, and $\mathrm{d}=$ pathlength $(1 \mathrm{~cm})$.
The protein concentration was determined by taking 10- $\mu \mathrm{L}$ samples from the tubes containing the DNP and their parallel blanks and adding $200 \mu \mathrm{L}$ of bicinchoninic acid solution (made up of $50 \mathrm{~mL}$ of bicinchoninic acid and $1 \mathrm{~mL}$ of $4 \% \mathrm{CuSO}_{4}$ solution), incubating them at $37^{\circ} \mathrm{C}$ for $30 \mathrm{~min}$, and then measuring the absorbance at $560 \mathrm{~nm}$. The carbonyl content in $\mathrm{nmol} / \mathrm{mg}$ protein of the samples was calculated by subtracting the reading from the parallel blanks, corresponding to a background count, from the tubes containing DNP. All samples were run in duplicate with an intraassay variability of $<5 \%$.

Statistical analysis. Data are presented as median values with ranges. Statistical analysis was performed using unpaired $t$ test for parametric data. Because no values were obtained from the HPLC determination of lipid hydroperoxides in the control samples (they were below the limit of detection), the data were analyzed using the Fisher Exact test (17).

\section{RESULTS}

Table 1 provides a summary of the demographic details of the control subjects and CF patients. Table 2 summarizes the concentrations of the four major antioxidants measured in the plasma of the two groups. Median $\alpha$-tocopherol concentrations for both groups were within the reported normal range (18), although a number of $\mathrm{CF}$ patients (10 of 33) had plasma vitamin E concentrations below the lower acceptable limit of $10 \mu \mathrm{mol} / \mathrm{L}$. In addition, a much wider distribution of $\alpha$-tocopherol concentrations was seen in CF patients, suggesting greater variability in dietary supply, efficiency of absorption of $\alpha$-tocopherol, or both.

Median plasma vitamin $\mathrm{C}$ concentrations were similar in the two groups. In control subjects, plasma vitamin C concentration ranged from 4.13 to $92.03 \mu \mathrm{mol} / \mathrm{L}$, with two individuals having concentrations below the reported normal range of $11-100 \mu \mathrm{mol} / \mathrm{L}$. The distribution in the CF group was similar, with concentrations ranging from 23.48 to $94.18 \mu \mathrm{mol} / \mathrm{L}$. There was, however, an agedependent decrease in plasma vitamin $\mathrm{C}$ concentration $(r$ $=-0.6, p=0.005$ ) in these patients. No differences with regard to gender were observed in any of the antioxidant concentrations within either group.

Plasma uric acid concentrations were found to be significantly lower in $\mathrm{CF}$ patients compared with agematched controls, although the median concentrations for both groups were within the reported normal range of

Table 1. Age and gender details for control subjects and $C F$ patients

\begin{tabular}{ccc}
\hline $\begin{array}{c}\text { Age range } \\
(\mathrm{y})\end{array}$ & $\begin{array}{c}\text { Controls } \\
\text { male/female }(n)\end{array}$ & $\begin{array}{c}\mathrm{CF} \\
\text { male/female }(n)\end{array}$ \\
\hline $0-5$ & $1 / 2$ & $5 / 5$ \\
$6-10$ & $2 / 4$ & $5 / 2$ \\
$11-15$ & $1 / 0$ & $9 / 6$ \\
$16-20$ & $0 / 0$ & $3 / 2$ \\
$>20$ & $1 / 0$ & $0 / 0$ \\
\hline
\end{tabular}


Table 2. Antioxidant concentrations ( $\mu \mathrm{mol} / \mathrm{L}$ ) in plasma of age-matched controls and $C F$ patients

\begin{tabular}{lcc}
\hline \multicolumn{1}{c}{ Antioxidant } & $\begin{array}{c}\text { Age-matched controls } \\
(n=9-11)\end{array}$ & $\begin{array}{c}\text { CF patients } \\
(n=20-33)\end{array}$ \\
\hline$\alpha$-Tocopherol & $15.10(12.96-26.57)$ & $14.81(3.65-28.54)$ \\
Vitamin C & $47.17(4.13-92.03)$ & $60.12(23.48-94.18)$ \\
Urate & $352.60(195.2-462.4)$ & $204.05(81.96-380.45)^{*}$ \\
Sulfhydryls & $631.40(525.49-814.71)$ & $574.50(400.2-1176.47)$ \\
\hline
\end{tabular}

* Statistical difference between groups $(p<0.01$ or better).

$120-420 \mu \mathrm{mol} / \mathrm{L}$ (19). CF patients showed a wider distribution in the plasma urate concentrations, with a range from 81.96 to $380.45 \mu \mathrm{mol} / \mathrm{L}$; four of the 22 patients examined had concentrations at or below the lower end of the normal range. However, no correlation was found between the concentration of uric acid and markers of lipid peroxidation and protein oxidation. Plasma sulfhydryl concentrations for the CF patients and age-matched control subjects did not differ significantly, but the median values for the two groups (574.50 and 631.40 $\mu \mathrm{mol} / \mathrm{L}$, respectively) were both at the high end of the reported normal range of 353-700 $\mu \mathrm{mol} / \mathrm{L}(19)$.

Indices of oxidative stress in age-matched control subjects and CF patients are shown in Figures 1 and 2 . Concentrations of TBA-reactive substances were significantly elevated in the patients with CF (range $=4.77$ $10.30 \mu \mathrm{mol} / \mathrm{L}$ ) compared with age-matched controls (range $=4.92-6.86 \mu \mathrm{mol} / \mathrm{L}$ ). There was a much larger distribution of values in the CF population, with a number of patients (11 of 26$)$ having concentrations in the plasma greater than $7 \mathrm{nmol} / \mathrm{L}$ (Fig. 1A). An agedependent increase in TBA-reactive substances was seen in the CF group $(r=0.54, p=0.007)$, a finding that has also been reported in normal populations by Yagi (20).

Fatty acid hydroperoxides, measured by HPLC, were also significantly elevated in CF patients compared with control subjects $(p<0.01)$. In 11 of the 33 CF patients studied, concentrations ranged from 0.022 to 0.34 $\mu \mathrm{mol} / \mathrm{L}$. In contrast, FFA hydroperoxides were not detected in $22 \mathrm{CF}$ patients or in any of the age-matched control plasma samples (Fig. $1 B$ ).

Plasma protein carbonyl concentrations did not differ significantly $(p=0.076)$ between the two groups (Fig. 2). In control subjects, concentrations ranged from 0.21 to $2.24 \mathrm{nmol} / \mathrm{mg}$ protein and the median concentration was in the reported normal range of $<1 \mathrm{nmol} / \mathrm{mg}$ protein (21). The median concentration of protein carbonyls for the CF group was $1.64 \mathrm{nmol} / \mathrm{mg}$ protein, but there was a much greater variation in the individual concentrations compared with the controls, with 15 of 28 patients having concentrations above the reported normal value of 1 $\mathrm{nmol} / \mathrm{mg}$ protein.

\section{DISCUSSION}

CF is characterized by abnormal mucosal secretions, particularly in the lung and gastrointestinal tract, which result in recurrent and severe bacterial and fungal chest
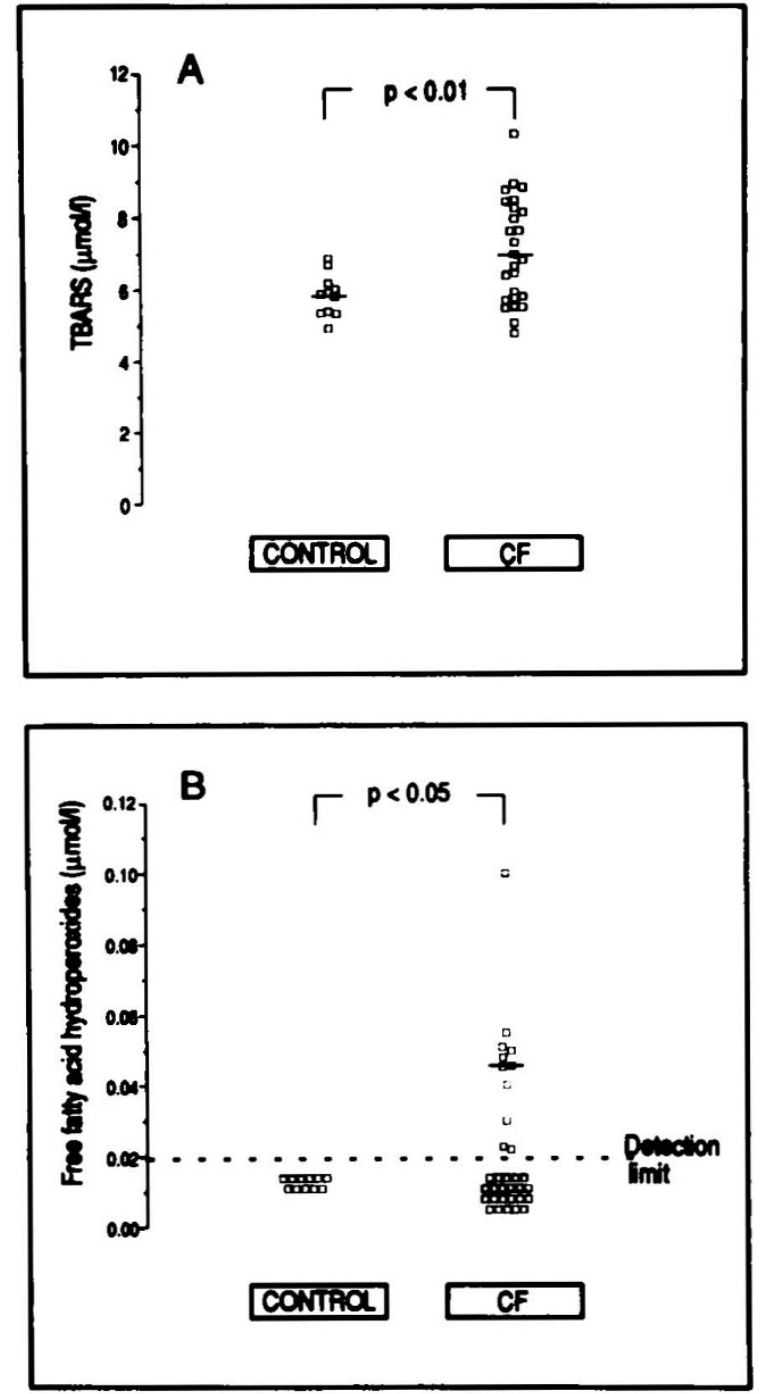

Figure 1. Markers of lipid peroxidation in control samples and samples from patients with $\mathrm{CF}$ showing the individual values within each group and the medians. $A$, TBA-reactive substances $(T B A R S)(n=11$ controls, $n=26$ CF patients). $B$, FFA lipid hydroperoxides $(n=11$ controls, $n=33$ CF patients).

infections and an impaired ability to absorb fat-soluble nutrients (22). Deficiencies of circulating antioxidants, especially vitamin E (23), serum albumin (24), and ferritin (25), have been previously reported in CF, and examination of the fluid lining the epithelium in the lung has shown it to be deficient in glutathione (26). Circulating (and presumably tissue) antioxidants are deficient in CF patients during periods of increased free radical flux, such as during bouts of acute pulmonary infection. Combined, these two events increase the oxidative burden on the lungs of the CF patient with the subsequent production of intermediates of free radical metabolism, which may then enter the circulation. We have addressed the question of antioxidant/free radical imbalance for two reasons. First, we believe that circulating free radical metabolites may represent sensitive markers of oxidative stress and may thus be useful in detecting those patients at risk at an early stage of imbalance. Second, because 


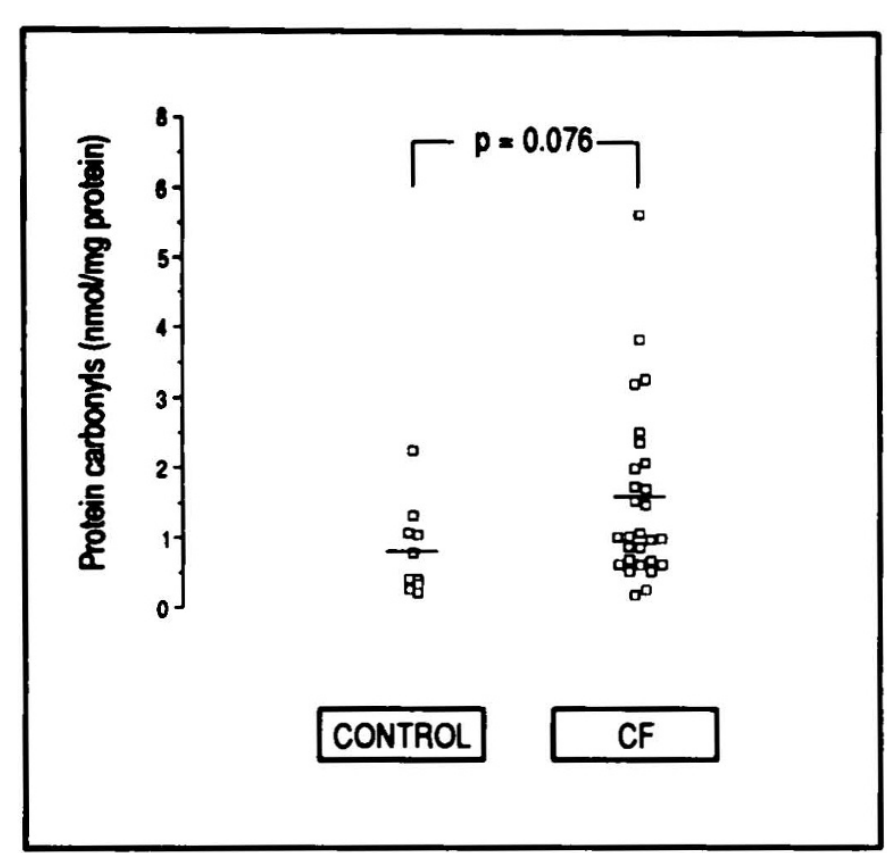

Figure 2. Plasma concentrations of protein carbonyls in control subjects and CF patients ( $n=11$ controls, $n=28 \mathrm{CF}$ patients).

many of the intermediate products of free radical metabolism are reactive in their own right, we believe they may be responsible for injury to other tissues in the body.

At the outset of the study, we decided to investigate the presence of markers of both lipid and protein oxidation. The most widely used method of measuring lipid oxidation involves the determination of malondialdehyde, a breakdown product of lipid peroxidation, by its reaction with TBA to form a colored product (15). Both control subjects and the CF patients enrolled in the study exhibited evidence of lipid peroxidation with this method. The median concentration of TBA-reactive substances was significantly increased in the $\mathrm{CF}$ population due to elevated concentrations in about $40 \%$ of the patients studied. The concentration of TBA-reactive substances in this subgroup of CF patients was comparable to that reported in patients with diabetes mellitus (27) and patients with acute hepatic failure (20). Because the TBA assay is not very specific and there have been concerns about its validity (28), it should no longer be used as a sole index of lipid peroxidation. For this reason, we also determined the concentration of FFA hydroperoxides in both groups.

Direct measurement of lipid hydroperoxides has only become possible with the advent of advanced HPLC technology, which enabled Yamamoto et al. (29) to develop an isoluminol-based, chemiluminescent assay for the determination of individual lipid hydroperoxides. Despite the greater sensitivity and specificity of this assay, no evidence of circulating lipid hydroperoxides was detected in control subjects. A similar observation was made by Holley and Slater (30). No evidence of circulating lipid hydroperoxides was found in $66 \%$ of the $\mathrm{CF}$ patients studied. The range of lipid hydroperoxides in the remaining patients varied considerably, with a 15 -fold difference being observed between the lowest and the highest concentrations. There was no correlation between TBA-reactive substances and lipid hydroperoxides, which is not altogether surprising considering the lack of specificity of the TBA test and the fact that the HPLC assay specifically measures oxidized FFA.

Lipids are not the only target for free radical attack in vivo; it is known that various amino acid residues including histidine, tryptophan, cysteine, proline, arginine, and lysine are particularly susceptible to oxidative attack (31). Oxidative damage to several of these residues as well as to the peptide backbone of proteins can lead to the formation of carbonyl products. We found no significant difference in markers of protein oxidation between controls and patients with CF (Fig. 2); however, a wider distribution in values was observed in the CF patients. Although the group as a whole showed no evidence of protein peroxidation, it does appear that some individuals were more susceptible, with seven patients having values greater than $2 \mathrm{nmol} / \mathrm{mg}$ protein. There was no correlation between markers of oxidative damage to lipids and protein carbonyls, which suggests that different mechanisms of damage are in operation or that the susceptibility to damage and breakdown of the subsequent metabolites differs between proteins and lipids.

We had assumed that the degree of oxidative damage would be reflected in the decreased antioxidant concentrations previously reported in CF. However, the concentrations of four main plasma antioxidants in the CF patients were all within reported normal ranges. This is not surprising, because all the patients were receiving vitamin supplements and the pancreatic enzyme Creon (Reid-Rowell, Marietta, GA). The program of dietary management and nutrient supplementation instituted at Southampton General Hospital has stabilized the plasma concentrations of vitamin $\mathrm{E}$ in $\mathrm{CF}$ patients as reported previously (6).

Both intracellular and extracellular antioxidant compartments come into contact with free radicals produced by activated neutrophils in the lung of the CF patient. In particular, the RTLF may be important in this respect. Although some information is available about the antioxidant capacity of this fluid $(32,33)$, sampling problems have greatly hindered elucidation of the precise chemical composition of RTLF. By contrast, the antioxidant defenses of human plasma have been well characterized and are seen by many as an acceptable model system in which to study events that are relevant to reactions occurring in $\operatorname{RTLF}(34,35)$. Indeed, it is hoped that plasma antioxidant capacity is representative in part of the antioxidant capacity of RTLF. It remains to be seen, however, how relevant such measurements in plasma are to the event that is taking place on the outer surface of the lung.

The role of the immune system in causing lung damage in patients with CF is now generally recognized (36). Much attention has focused on the effects of elastase secreted by neutrophils in mediating this damage $(8,37)$, 
yet the direct contributory role of oxidant species has been largely ignored. A recent study has shown that, in addition to neutrophils as a source of free radicals, two secretory products of Pseudomonas aeruginosa, the most commonly found pathogenic bacterium in CF, are capable of damaging local tissues through the generation of hydroxyl radicals (38). Thus, the degree of colonization by bacterial strains and the severity of the lung infection will have an important bearing on the production of free radicals and consequently on the resulting damage. However, although it has been established that $P$. aeruginosa is an important stimulus for lower respiratory tract inflammation in $\mathrm{CF}$, a recent study has shown that the burden of pathogens in bronchoalveolar lavage fluid does not appear to correlate with the degree of inflammation observed (39).

For an effective immune response to take place, the role of activated neutrophils in combating infection must outweigh any pulmonary damage inflicted by their excessive production of oxidizing species. Similarly, antioxidant therapy must attempt to prevent the latter without compromising the host's response to infection. A number of studies have investigated the effects of excess supplementation on immunologic status concentrating on vitamins C, E, and A (40-42). No detrimental effects of elevated vitamin supplementation on the immune system have been shown, and in fact mitogen response may be enhanced. Therefore, provision of a cocktail of antioxidants containing vitamin $\mathrm{E}$, vitamin $\mathrm{C}$, and possibly uric acid capable of elevating plasma antioxidants to the top of normal reported ranges while not unduly affecting the immune system may diminish oxidative lung damage. Caution should, however, be exercised with vitamin C supplementation, because vitamin $\mathrm{C}$ can act as a prooxidant in the presence of free iron. This may not be a problem in CF patients, because bacterial siderophores produced by $P$. aeruginosa bind most of the free iron available in the airway lining fluid (43).

The results of this study provide evidence of increased lipid peroxidation in patients with $\mathrm{CF}$ and show that certain individuals may be more susceptible to oxidative damage to both lipids and proteins even in the presence of normal concentrations of the main plasma antioxidants. Furthermore, the results confirm the validity of the current belief in the management of $\mathrm{CF}$ that decreasing the inflammatory response may prevent excessive damage (10). However, increased antioxidant supplementation on an individual basis may also play a part in clinical management, inasmuch as evidence of damage was observed even in the presence of normal plasma antioxidant concentrations.

Acknowledgments. The authors thank Professor J. O. Warner and Dr. S. Peters for their kind help, and B. Austin for sample collection and her excellent technical assistance. We also thank all the patients and their parents for their participation in this study.

\section{REFERENCES}

1. McNurlan MA, Tomkins AM, Garlick PJ 1979 The effect of starvation on the rate of protein synthesis in rat liver and small intestine. Biochem J 178:373 379

2. Munro JM, Cotran RS 1988 The pathogenesis of atherosclerosis: atherogenesis and inflammation. Lab Invest 58:249-253

3. Ames BN 1989 Endogenous oxidative DNA damage, aging, and cancer. Free Radic Res Commun 7:121-128

4. Bilton D, Maddison J, Webb AK, Seabra L, Jones M, Braganza JM 1991 Cystic fibrosis, breath pentane and lipid peroxidation. Lancet 337:1420(abstr)

5. Salh B, Webb K, Guyan PM, Day JP, Wickens D, Griffin J, Braganza JM, Dormandy TL 1989 Aberrant free radical activity in cystic fibrosis. Clin Chim Acta 181:65-74

6. Langley SC, Brown RK, Kelly FJ 1993 Reduced free-radical-trapping capacity and altered plasma antioxidant status in cystic fibrosis. Pediatr Res 33:247-250

7. McMillan DD, Boyd GN 1982 The role of antioxidants and diet in the prevention or treatment of oxygen-induced lung microvascular injury. Ann NY Acad Sci 384:535-543

8. Doring G, Albus A, Hoiby N 1988 Immunological aspects of cystic fibrosis. Chest 94:109S-115S

9. Kharazmi A, Rechnitzer C, Schiotz PO, Jensen T, Back L, Hoiby N 1987 Priming of neutrophils for enhanced oxidative burst by sputum from cystic fibrosis patients with Pseudomonas aeruginosa infection. Eur J Biochem 17:256-261

10. Holsclaw DS 1993 Cystic fibrosis and pulmonary involvement from multiple perspectives. Semin Respir Infect 7:141-150

11. Babior BM 1987 The respiratory burst oxidase. Trends Biomed Sci 12:241243

12. Kelly FJ, Rodgers W, Handel J, Smith S, Hall MA 1990 Time course of vitamin $E$ repletion in the premature infant. Br J Nutr 63:631-638

13. Iriyama K, Yoshiura M, Iwamoto T, Ozaki Y 1984 Simultaneous determination of uric acid and ascorbic acid in human serum by reversed-phase high-performance liquid chromatography with electrochemical detection. Anal Biochem 141:2387-2243

14. Ellman GL 1959 Tissue sulphydryl groups. Arch Biochem Biophys 82:70-77

15. Yagi K 1984 Assay for blood plasma or serum. In: Packer L (ed) Methods in Enzymology. Academic Press, London, pp 328-331

16. Levine RL, Garland D, Oliver CN, Amici A, Climent I, Lenz AG, Ahn BW Shaltiel S, Stadman ER 1990 The determination of carbonyl content in oxidatively modified proteins. In: Packer L, Glazer AN (eds) Methods in Enzymology, Vol 186. Academic Press, London, pp 464-477

17. Zar JH 1984 The Binomial Distribution. In: Kurtz B (ed) Biostatistical Analysis. Prentice-Hall, NJ, pp 369-405

18. Ehrenkranz RA 1980 Vitamin E and the neonate. Am J Dis Child 134:11571166

19. Thurnham DI 1990 Antioxidants and prooxidants in malnourished populations. Proc Nutr Soc 49:247-259

20. Yagi K 1987 Lipid peroxides and human diseases. Chem Phys Lipids 45:337351

21. Reznick AZ, Cross CE, Hu ML, Suzuki YJ, Khwaja S, Safadi A, Motchnik PA, Packer L, Halliwell B 1992 Modification of plasma proteins by cigarette smoke as measured by protein carbonyl formation. Biochem J 286:607-611

22. Chase HP, Long M, Lavin M 1979 Cystic fibrosis and malnutrition. J Pediatr 95:337-347

23. Bye AME, Muller DPR, Wilson J, Wright VM, Mearns MB 1985 Symptomatic vitamin E deficiency in cystic fibrosis. Arch Dis Child 60:162-164

24. Reisman J, Petrou C, Corey M, Stringer D, Durie P, Levison H 1989 Hypoalbuminemia at initial examination in patients with cystic fibrosis. J Pediatr 115:755-758

25. Ehrhardt P, Miller MG, Littlewood JM 1987 Iron deficiency in cystic fibrosis. Arch Dis Child 62:185-187

26. Roum JH, Buhl R, McElvaney NG, Borok Z, Hubbard RC, Chernick M, Cantin AM, Crystal RG 1990 Cystic fibrosis is characterized by a marked reduction in glutathione levels in pulmonary epithelial lining fluid. Am Rev Respir Dis 141:A87(abstr)

27. Sato Y, Hotta N, Saxamoto N, Matsuoka S, Ohnishi N, Yagi K 1979 Lipid peroxide level in plasma of diabetic patients. Biochem Med 21:104-107

28. Esterbauer H, Cheeseman KH 1990 Determination of aldehydic lipid peroxidation products: malonaldehyde and 4-hydroxynonenal. In: Packer L, Glazer AN (eds) Methods in Enzymology, Vol 186. Academic Press, London, pp $407-421$

29. Yamamoto Y, Brodsky MH, Baker JC, Ames BN 1987 Detection and characterization of lipid hydroperoxides at picomole levels by high-performance liquid chromatography. Anal Biochem 160:7-13

30. Holley AE, Slater TF 1991 Measurement of lipid hydroperoxides in normal human blood plasma using HPLC-chemiluminescence linked to a diode array detector for measuring conjugated dienes. Free Radic Res Commun 15:51-63

31. Stadtman ER 1990 Metal ion-catalyzed oxidation of proteins: biochemical mechanism and biological consequences. Free Radic Biol Med 9:315-325

32. Heffner JE, Repine JE 1989 Pulmonary strategies of antioxidant defense. Am Rev Respir Dis 140:531-554

33. Cantin AM, North SL, Hubbard RC, Crystal RG 1987 Normal alveolar epithelial lining fluid contains high levels of glutathione. J Appl Physiol 63:152-157 
34. Cross CE, Reznick AZ, Packer L, Davis PA, Suzuki YJ, Halliwell B 1992 Oxidative damage to human plasma proteins by ozone. Free Rad Res Commun 15:347-352

35. Halliwell B, Gutteridge JMC 1990 The antioxidants of human extracellular fluids. Arch Biochem Biophys 280:1-8

36. Warner JO 1992 Immunology of cystic fibrosis. Br Med Bull 47:893-911

37. Bruce MC, Poncz L, Klinger JD, Stern RC, Tomashefski JF, Dearborn DG 1985 Biochemical and pathologic evidence for proteolytic destruction of lung connective tissue in cystic fibrosis. Am Rev Respir Dis 132:529-535

38. Britigan BE, Roeder TL, Rasmussen GT, Shasby DM, McCormick ML, Cox CD 1992 Interaction of the Pseudomonas aenuginosa secretory products pyocyanin and pyochelin generates hydroxyl radical and causes synergistic damage to endothelial cells. J Clin Invest 90:2187-2196
39. Meyer KC, Zimmerman J 1993 Neutrophil mediators, Pseudomonas, and pulmonary dysfunction in cystic fibrosis. J Lab Clin Med 121:654-661

40. Goodwin JS, Garry PJ 1983 Relationship between megadose vitamin supplementation and immunological function in a healthy elderly population. Clin Exp Immunol 51:647-653

41. Anderson R, Dosthuizen R, Maritz R, Theron A, Van Rensburg AJ 1980 The effect of increasing weekly doses of ascorbate on certain cellular and humoral immune functions in normal volunteers. Am J Clin Nutr 33:71-80

42. Boxer LA 1990 The role of antioxidants in modulating neutrophil functional responses. Adv Exp Med Biol 262:19-33

43. Terry JM, Piña SE, Mattingly SJ 1992 Role of energy metabolism in conversion of nonmucoid Pseudomonas aenuginosa to the mucoid type. Infect Immun 60:1329-1335

\section{Announcement}

\section{The Society for Adolescent Medicine Annual Meeting}

The Society for Adolescent Medicine, a multidisciplinary organization, will hold its annual meeting in Vancouver, British Columbia, on March 22-25, 1995, at the Vancouver Trade and Convention Center with the Waterfront Hotel as host hotel. The theme for the meeting will be "International Perspectives on Adolescent Health." In addition to addressing this topic, the meeting will present new material on a broad range of issues important to adolescent physical and emotional health, including AIDS and HIV medical management, teenage sexuality, eating disorders, depression, and risk-taking behaviors, which encompass drug and alcohol use and abuse. Meeting presentations include 3-hour clinically oriented workshops, luncheon seminars, and scientific research paper presentations and poster sessions, as well as the prestigious Gallagher Lecture Series. CME/CEUs are available.

For further information, contact the Society for Adolescent Medicine, Suite 120, 19401 E. 40 Highway, Independence, MO 64055, (816) 795-8336. 